\title{
Prevalensi HIV dan HBV pada Kalangan Remaja
}

\author{
Patricia Gita Naully ${ }^{1}$, Sitti Romlah ${ }^{2}$ \\ ${ }^{1,2}$ Program Studi Analis Kesehatan, STIKES Jenderal Achmad Yani Cimahi, Indonesia \\ Email: patriciagitanaully@gmail.com
}

\begin{abstract}
HIV and HBV Prevalence among Adolescences. Human Immunodeficiency Virus (HIV) is a virus that infects a human immune system. HIV route of transmission is similar to Hepatitis B Virus (HBV), which is a virus that causes cirrhosis and liver cancer. Infection of HIV and HBV still remain a health problem in Indonesia. In Cimahi City, the number of HIV case is increasing, including in teenagers. Therefore, this study aims to determine HIV and HBV prevalence among teenager aged 15-19 years old who live in sub-district South Cimahi. The sample used is from adolescents aged 15-19 years who live in District Cimahi South. Venipuncture is done only on respondents who have filled informed consent and questionnaire. Laboratory testing conducted consisted of anti-HIV and HBsAg testing using immunochromatography. Data obtained from laboratory testing is analyzed using a logistic regression method. Of 100 adolescence, one person is found infected with HIV and two are infected with HBV. Based on statistical data, age; education; and frequent changes in sexual partners, significantly influence the HIV prevalence $(p<0.05)$. In HBV, factors that significantly influence prevalence are: age, education, piercing, and vaccination $(\mathrm{p}<0.05)$. From all the results it can be concluded that HIV and HBV case among adolescents aged 15-19 years found in sub-district of South Cimahi has the prevalence of $1 \%$ for HIV and $2 \%$ for HBV.
\end{abstract}

Keywords: Anti-HIV, HBsAg, Immunochromatography, Teenager

\begin{abstract}
Abstrak: Prevalensi HIV dan HBV pada Kalangan Remaja. Human Immunodeficiency Virus (HIV) merupakan virus yang menyerang sistem imun manusia. Virus ini memiliki kesamaan jalur transmisi dengan Hepatitis B Virus (HBV), yaitu virus yang dapat menyebabkan sirosis dan kanker hati. Infeksi HIV dan HBV masih menjadi permasalahan kesehatan di Indonesia. Di Kota Cimahi jumlah kasus HIV semakin meningkat, termasuk pada kalangan remaja. Oleh karena itu, penelitian ini bertujuan untuk menentukan prevalensi HIV dan HBV pada kalangan remaja usia 15-19 tahun di Kecamatan Cimahi Selatan. Sampel yang digunakan adalah remaja usia 15-19 tahun yang bertempat tinggal di Kecamatan Cimahi Selatan. Pengambilan darah vena hanya dilakukan pada responden yang sudah mengisi informed consent dan kuesioner. Pemeriksaan laboratorium yang terdiri dari pemeriksaan anti-HIV dan HBsAg dilakukan menggunakan imunokromatografi. Data laboratorium dianalisis menggunakan metode regresi logistik.Dari 100 orang remaja, terdapat satu orang terinfeksi HIV dan dua orang terinfeksi HBV. Berdasarkan data statistik, faktor usia, pendidikan, dan seringnya berganti-ganti pasangan seksual berpengaruh secara signifikan terhadap prevalensi HIV $(p<0,05)$. Pada prevalensi HBV faktor yang berpengaruh secara signifikan adalah usia, pendidikan, tindik, dan vaksinasi $p<0,05)$. Dari seluruh hasil dapat disimpulkan bahwa kasus HIV dan HBV pada kalangan remaja usia 15-19 tahun ditemukan di Kecamatan Cimahi Selatan dengan prevalensi sebesar $1 \%$ untuk HIV dan $2 \%$ untuk HBV.
\end{abstract}

Kata kunci: Anti-HIV, HBsAg, Imunokromatografi, Remaja

Human Immunodeficiency Virus (HIV) adalah retrovirus yang biasanya menyerang makrofaga dan sel $\mathrm{T}$ dalam sistem imun manusia (Murphy, 2012). Infeksi HIV dapat menyebabkan kondisi yang disebut dengan Acquired Immune Deficiency Syndrome (AIDS). Virus tersebut dapat ditransmisikan dengan dua cara, yaitu vertikal dan horizontal (Kudesia dan Wreghitt, 
2009). Cara vertikal adalah cara penularan dari ibu ke anak ketika dalam kandungan, proses kelahiran, atau menyusui. Cara horizontal adalah cara penularan dari orang dewasa ke orang dewasa lainnya melalui aktivitas seksual, tranfusi darah, dan penggunaan jarum yang terkontaminasi secara bersamaan seperti pada pembuatan tato, tindik, dan narkoba jarum suntik. HIV memiliki kesamaan jalur transmisi dengan beberapa virus lain, salah satunya adalah Hepatitis B Virus (HBV) (Mohammadi et al., 2009). HBV adalah hepadnavirus yang menyerang sel hati dan dapat menyebabkan sirosis, kanker hati, hingga kematian (Murphy, 2012).

Sampai saat ini, infeksi HIV dan HBV masih menjadi salah satu permasalahan kesehatan dunia. Sebagai negara berkembang dengan jumlah penduduk yang banyak, Indonesia juga mengalami masalah kesehatan yang sama. Indonesia sempat dinyatakan sebagai negara dengan pengidap Hepatitis B tertinggi nomor dua di ASEAN. Data Kementerian Kesehatan Republik Indonesia menunjukkan bahwa ada sekitar 18 juta orang Indonesia yang terinfeksi HBV (Kementerian Kesehatan RI, 2014). Jumlah kasus infeksi HIV di Indonesia juga terus meningkat, terbukti dengan adanya 33.660 kasus baru pada tahun 2017 dengan total kumulatif 242.699 orang yang terinfeksi HIV (Kementerian Kesehatan RI, 2017).

Infeksi HIV dan HBV paling banyak terjadi pada kelompok usia dewasa yaitu usia 2549 tahun dan 20-24 tahun. Namun, terdapat fakta yang mengejutkan pada kalangan remaja kelompok usia 15-19 tahun. Jumlah remaja yang terinfeksi HIV di Indonesia semakin meningkat, dengan prevalensi sekitar 3,2-3,8\% setiap tahunnya. Hingga bulan April 2017, tercatat ada 7.329 remaja yang terinfeksi HIV dan 2.355 orang diantaranya menderita (AIDS) (Kementerian Kesehatan RI, 2017). Hal ini sungguh memprihatinkan, mengingat remaja usia 15-19 tahun merupakan generasi penerus bangsa.

Menurut Viegas et al. (2015), banyaknya kasus infeksi HIV dan HBV pada kalangan remaja terjadi karena keterbatasan akses informasi dan layanan kesehatan terkait penyakit tersebut. Survei Riskesdas 2010 menunjukkan bahwa sekitar $42 \%$ dari jumlah penduduk usia di atas 15 tahun belum pernah mendengar tentang HIV atau HBV padahal usia inisiasi seks di Indonesia relatif sangat muda (Sudikno et al., 2011). Berdasarkan data United Nations Development Economis and Social Affairs tahun 2010, Indonesia merupakan negara dengan persentase pernikahan usia muda tertinggi kedua di ASEAN (Kementerian Kesehatan RI, 2015).

Pada tahun 2012, tercatat ada 4,5\% remaja pria dan 0,7\% remaja wanita usia 15-19 tahun yang telah melakukan aktivitas seksual pra nikah (Kementerian Kesehatan, 2015). Pratiwi dan Basuki (2011) dalam Media (2016) menyebutkan bahwa remaja memiliki rasa keingintahuan yang besar dan mudah terpengaruh lingkungan sekitarnya. Remaja sering kali melakukan hubungan seksual atau hal lain hanya untuk memuaskan rasa ingin tahu mereka. Menurut Purwaningsih dan Widayatun (2008) tingginya kasus HIV dan HBV pada remaja usia 15-19 tahun terjadi karena banyak wanita yang bekerja menjadi Pekerja Seks Komersial (PSK) di usia muda. Selain melalui hubungan seksual, remaja juga dapat tertular HIV dan HBV melalui narkoba jarum suntik (Viegas et al., 2015).

Tingginya kasus HIV pada kalangan remaja juga terjadi di kota Cimahi. Tercatat sejak tahun 2007 hingga 2016 ada 290 kasus HIV yang mayoritas berasal dari kalangan ekonomi menengah ke bawah dan berada dalam rentang usia 15-25 tahun (Dinas Kesehatan Kota Cimahi, 2017). Selain itu, ada hal yang cukup menarik pada data infeksi HBV di Kota Cimahi. Menurut Dinas Kesehatan Kota Cimahi (2017), tidak ada kasus infeksi HBV yang terjadi di kota tersebut. Jika ditinjau dari jalur transmisi HIV dan HBV yang telah dipaparkan diatas, besar kemungkinan bahwa infeksi HBV terjadi pada kalangan remaja di Cimahi seiring dengan banyaknya remaja yang terinfeksi HIV. Mengingat kasus HIV dan HBV seperti fenomena gunung es dimana data yang nampak hanya sebagian kecil dari kenyataan sebenarnya, maka pemeriksaan HIV dan HBV pada kalangan remaja di Cimahi perlu dilakukan secara luas.

Berdasarkan data Badan Pusat Statistik Kota Cimahi (2017), penduduk remaja usia 15-19 tahun di Cimahi berjumlah 53.407 jiwa. Jumlah penduduk remaja tertinggi ada di Kecamatan Cimahi Selatan, yaitu 22.500 jiwa. Oleh karena itu, penelitian ini bertujuan untuk menentukan prevalensi HIV dan HBV pada kalangan remaja usia 15-19 tahun yang berdomisili di Kecamatan Cimahi Selatan.

\section{METODE}

Pengumpulan sampel dilakukan pada bulan Juli 2018. Jumlah sampel ditentukan menggunakan rumus Slovin. Untuk mendapatkan tingkat keakuratan data lebih dari 90\% maka sampel yang digunakan adalah 100 orang remaja 
dengan rentang usia 15-19 tahun yang bertempat tinggal di Kecamatan Cimahi Selatan. Sebelum dilakukan pengambilan darah vena, para remaja tersebut diminta untuk mengisi kuesioner yang berisikan 15 pertanyaan terbuka. Pertanyaan tersebut terkait dengan identitas, aktivitas seksual, gaya hidup, dan riwayat penyakit.

\section{Pemeriksaan Anti-HIV}

Penelitian ini menggunakan tiga strategi pemeriksaan laboratorium untuk mendiagnosis infeksi HIV pada sampel. Ketiga strategi tersebut mengacu pada Peraturan Menteri Kesehatan Republik Indonesia Nomor 15 Tahun 2015. Pemeriksaan anti-HIV dilakukan menggunakan imunokromatografi yang dapat mendeteksi infeksi oleh HIV-1 dan HIV-2. Imunokromatografi yang digunakan dalam setiap strategi memiliki karakteristik yang berbeda (Tabel 1).

Tabel 1. Karakteristik Imunokromatografi Anti-HIV1 dan HIV-2

\begin{tabular}{crr}
\hline Strategi & Sensitivitas (\%) & \multicolumn{1}{c}{ Spesifisitas (\%) } \\
\hline I & 100 & 98,80 \\
II & 99,33 & 99,43 \\
III & 100 & 100 \\
\hline
\end{tabular}

\section{Pemeriksaan HbsAg}

Pemeriksaan Hepatitis B yang dilakukan dalam penelitian ini terdiri dari dua tahap. Sampel yang positif HBsAg pada pemeriksaan tahap pertama diperiksa kembali pada tahap kedua menggunakan metode yang sama namun dengan reagen yang berbeda. Keberadaan HBsAg dalam darah dideteksi menggunakan imunokromatografi dengan sensitivitas dan spesifisitas yang tinggi (Tabel 2).

Tabel 2. Karakteristik Imunokromatografi HBsAg

\begin{tabular}{ccr}
\hline Tahap & Sensitivitas (\%) & Spesifisitas (\%) \\
\hline I & 99,00 & 97,00 \\
II & 99,30 & 98,30 \\
\hline
\end{tabular}

Data hasil pemeriksaan laboratorium HIV dan HBV diolah dan dianalisis dengan metode regresi logistik menggunakan perangkat lunak Minitab versi 18. Metode ini digunakan untuk mengetahui hubungan yang signifikan antara faktor-faktor penyebab dengan prevalensi infeksi HIV dan HBV.

Penelitian ini sudah disetujui oleh Komisi Etik Penelitian Kesehatan Stikes Jenderal Achmad Yani Cimahi dengan nomor etik 10/KEPK/VII/2018. Seluruh responden setuju untuk ikut serta dalam penelitian ini setelah diberikan infomasi mengenai tujuan, prosedur, resiko, dan hal lain terkait penelitian. Responden juga telah mengisi serta menandatangani informed consent yang sesuai dengan ketentuan etik yang berlaku. Informed consent bagi responden yang berusia dibawah 18 tahun diisi oleh orang tua atau wali yang bersangkutan.

HASIL

Tabel 3. Prevalensi HIV dan HBV pada Kalangan Remaja Berdasarkan Sosio Demografik

\begin{tabular}{|c|c|c|c|c|c|c|c|c|}
\hline \multirow{2}{*}{ Variabel } & \multicolumn{2}{|c|}{ Total } & \multicolumn{3}{|c|}{ Positif Anti-HIV } & \multicolumn{3}{|c|}{ Positif HBsAg } \\
\hline & $\mathbf{n}$ & $\%$ & $\%$ & Koef.Regresi & $p$-value & $\%$ & Koef.Regresi & $p$-value \\
\hline Jenis Kelamin & & & & 0,0023 & 0,0700 & & 0,0015 & 0,0789 \\
\hline Laki-Laki & 62 & 62 & 1,6 & & & 1,6 & & \\
\hline Perempuan & 38 & 38 & 0,0 & & & 2,6 & & \\
\hline Usia (Tahun) & & & & 0,0355 & 0,0441 & & 0,0299 & 0,0139 \\
\hline 15 & 20 & 20 & 0,0 & & & 0,0 & & \\
\hline 16 & 20 & 20 & 0,0 & & & 0,0 & & \\
\hline 17 & 20 & 20 & 0,0 & & & 0,0 & & \\
\hline 18 & 20 & 20 & 5,0 & & & 5,0 & & \\
\hline 19 & 20 & 20 & 0,0 & & & 5,0 & & \\
\hline Pendidikan & & & & 0,0394 & 0,0382 & & 0,0135 & 0,0249 \\
\hline SD & 16 & 16 & 6,3 & & & 0,0 & & \\
\hline SMP & 25 & 25 & 0,0 & & & 4,0 & & \\
\hline SMA & 27 & 27 & 0,0 & & & 3,7 & & \\
\hline Perguruan Tinggi & 32 & 32 & 0,0 & & & 0,0 & & \\
\hline Pekerjaan & & & & 0,0455 & 0,1890 & & 0,0287 & 0,0698 \\
\hline Pelajar & 53 & 53 & 0,0 & & & 0,0 & & \\
\hline Pengamen & 40 & 40 & 2,5 & & & 5,0 & & \\
\hline Buruh Pabrik & 7 & 7 & 0,0 & & & 0,0 & & \\
\hline
\end{tabular}


Penelitian ini melibatkan 100 orang responden yang terdiri dari 62 orang laki-laki dan 38 orang perempuan. Seluruh responden berusia 15-19 tahun dan tiap usia diwakili oleh 20 orang. Pendidikan responden yang paling banyak adalah perguruan tinggi (32\%). Pekerjaan responden yang paling banyak adalah pelajar $(53 \%)$ diikuti dengan pengamen $(40 \%)$. Hasil pengolahan data statistik menunjukkan bahwa faktor usia dan pendidikan berpengaruh secara signifikan terhadap prevalensi HIV dan HBV pada kalangan remaja di Cimahi Selatan (Tabel 3).

Data yang ditampilkan merupakan hasil pengolahan statistik menggunakan metode regresi logistik. Setiap faktor yang memiliki nilai $p$ kurang dari 0,05 dinyatakan berpengaruh secara signifikan terhadap prevalensi HIV atau HBV pada remaja di Cimahi Selatan. Faktor lain yang memiliki nilai $p$ lebih dari 0,05 tetap berpengaruh terhadap prevalensi kedua virus tersebut, namun tidak signifikan.
Selain faktor sosio demografi, ada beberapa karakteristik gaya hidup yang berpengaruh secara signifikan terhadap prevalensi HIV dan HBV (Tabel 4). Gaya hidup yang sering berganti-ganti pasangan seksual menjadi faktor yang berpengaruh secara signifikan terhadap prevalensi HIV $(p=0,0167)$. Gaya hidup seperti menindik tubuh dan tidak melakukan vaksinasi hepatitis B menjadi faktor yang berpengaruh secara signifikan terhadap prevalensi HBV dengan nilai $p 0,0343$ untuk tindik dan 0,0421 untuk vaksinasi.

Berdasarkan hasil wawancara, terdapat 32 orang remaja yang mengaku pernah melakukan hubungan seksual pra nikah, 17 orang diantaranya sering berganti-ganti pasangan dan 6 orang tidak pernah menggunakan kondom. Pada penelitian ini tidak ada responden yang menggunakan narkoba jarum suntik dan pernah melakukan transfusi darah sebelumnya.

Tabel 4. Prevalensi HIV dan HBV pada Kalangan Remaja Berdasarkan Gaya Hidup

\begin{tabular}{|c|c|c|c|c|c|c|c|c|}
\hline \multirow{2}{*}{ Variabel } & \multicolumn{2}{|c|}{ Total } & \multicolumn{3}{|c|}{ Positif Anti-HIV } & \multicolumn{3}{|c|}{ Positif HBsAg } \\
\hline & n & $\%$ & $\%$ & Koef.Regresi & $p$-value & $\%$ & Koef.Regresi & $p$-value \\
\hline Jumlah Subjek & 100 & 100 & 1,0 & & & 2,0 & & \\
\hline Hubungan Seksual & & & & 0,0324 & 0,2778 & & 0,0924 & 0,0865 \\
\hline Pernah & 32 & 32 & 3,1 & & & 6,3 & & \\
\hline Tidak Pernah & 68 & 68 & 0,0 & & & 0,0 & & \\
\hline Berganti-ganti pasangan & & & & 0,0499 & 0,0167 & & 0,0512 & 0,1065 \\
\hline Ya & 17 & 17 & 5,9 & & & 11,8 & & \\
\hline Tidak & 83 & 83 & 0,0 & & & 0,0 & & \\
\hline Penggunaan kondom & & & & 0,0445 & 0,3768 & & 0,0098 & 0,7125 \\
\hline $\mathrm{Ya}$ & 6 & 6 & 0,0 & & & 0,0 & & \\
\hline Tidak & 94 & 94 & 1,1 & & & 2,1 & & \\
\hline Oral & & & & 0,0987 & 0,7341 & & 0,0210 & 0,1098 \\
\hline Ya & 4 & 4 & 25,0 & & & 0,0 & & \\
\hline Tidak & 96 & 96 & 0,0 & & & 2,1 & & \\
\hline Anal & & & & 0,0098 & 0.6416 & & 0,0099 & 0.2991 \\
\hline Ya & 0 & 0 & 0,0 & & & 0,0 & & \\
\hline Tidak & 100 & 100 & 1,0 & & & 2,0 & & \\
\hline Transfusi Darah & & & & 0,0067 & 0,5510 & & 0,0187 & 0,2088 \\
\hline Pernah & 3 & 3 & 0,0 & & & 0,0 & & \\
\hline Tidak Pernah & 97 & 97 & 1,0 & & & 2,0 & & \\
\hline Narkoba Jarum Suntik & & & & 0,0139 & 0,6288 & & 0,0978 & 0,7178 \\
\hline Ya & 0 & 0 & 0,0 & & & 0,0 & & \\
\hline Tidak & 100 & 100 & 1,0 & & & 2,0 & & \\
\hline Tato & & & & 0,0127 & 0,1347 & & 0,0670 & 0,3547 \\
\hline Ya & 25 & 25 & 4,0 & & & 4,0 & & \\
\hline Tidak & 75 & 75 & 0,0 & & & 1,3 & & \\
\hline Tindik & & & & 0,0087 & 0,1119 & & 0,0099 & 0,0343 \\
\hline Ya & 37 & 37 & 2,7 & & & 2,0 & & \\
\hline Tidak & 63 & 63 & 0,0 & & & 0,0 & & \\
\hline Vaksinasi Hepatitis B & & & & $-0,0398$ & 0.2084 & & $-0,0041$ & 0,0421 \\
\hline Pernah & 45 & 45 & 0,0 & & & 0,0 & & \\
\hline Tidak Pernah & 55 & 55 & 1,8 & & & 3,6 & & \\
\hline
\end{tabular}

Untuk melakukan diagnosis penyakit yang akurat, hasil pemeriksaan laboratorium harus didukung dengan gejala klinis dari responden. Oleh karena itu, ada beberapa pertanyaan kuesioner tentang riwayat penyakit responden. Riwayat penyakit yang diajukan 
terkait dengan gejala klinis penyakit Hepatitis B dan HIV. Hasil kuesioner tersebut menunjukkan bahwa remaja yang terinfeksi HIV pernah mengalami diare dan penurunan berat badan sekitar $10 \%$ dari bobot tubuhnya tanpa alasan yang jelas. Selain itu, ada satu orang responden yang pernah mengalami infeksi kelamin.

Tabel 5. Riwayat Penyakit Responden Penelitian

\begin{tabular}{|c|c|c|c|c|c|c|c|c|}
\hline \multirow[b]{2}{*}{ Variabel } & \multicolumn{2}{|c|}{ Total } & \multicolumn{3}{|c|}{ Positif Anti-HIV } & \multicolumn{3}{|c|}{ Positif HBsAg } \\
\hline & $\mathbf{n}$ & $\%$ & $\%$ & $\begin{array}{l}\text { Koefisien } \\
\text { regresi }\end{array}$ & p-value & $\%$ & $\begin{array}{l}\text { Koefisien } \\
\text { regresi }\end{array}$ & $p$-value \\
\hline Jumlah Subjek & 100 & 100 & 1,0 & & & 2,0 & & \\
\hline $\begin{array}{l}\text { Penurunan berat badan } \\
\text { drastis }\end{array}$ & & & & 0,0185 & 0,0989 & & 0,0018 & 0,0956 \\
\hline Pernah & 3 & 3 & 33,3 & & & 0,0 & & \\
\hline Tidak Pernah & 97 & 97 & 0,0 & & & 2,1 & & \\
\hline Diare berkepanjangan & & & & 0,0598 & 0,0651 & & 0,0032 & 0,0661 \\
\hline Pernah & 5 & 5 & 20 & & & 0,0 & & \\
\hline Tidak Pernah & 95 & 95 & 0,0 & & & 2,1 & & \\
\hline Infeksi daerah kelamin & & & & 0,0778 & 0,0798 & & 0,0182 & 0,0812 \\
\hline Pernah & 7 & 7 & 0,0 & & & 14,2 & & \\
\hline Tidak Pernah & 93 & 93 & 1,1 & & & 1,1 & & \\
\hline Penyakit Kuning & & & & 0,0099 & 0,0595 & & 0,0119 & 0,0986 \\
\hline Pernah & 0 & 0 & 0,0 & & & 0,0 & & \\
\hline Tidak Pernah & 100 & 100 & 1,0 & & & 0 & & \\
\hline
\end{tabular}

\section{PEMBAHASAN}

Hasil penelitian ini menunjukkan bahwa dari 100 orang remaja yang berdomisili di Kecamatan Cimahi Selatan, terdapat satu orang (1\%) yang terinfeksi HIV dan dua orang (2\%) yang terinfeksi HBV. Angka prevalensi HBV lebih tinggi dari HIV. Hasil yang serupa dilaporkan pula oleh Viegas et al. (2015). Dalam penelitiannya, tercatat prevalensi HBV pada kalangan remaja di Mozambique, Afrika adalah $12,2 \%$ sedangkan angka prevalensi HIV hanya $5,1 \%$. Hasil penelitian ini juga didukung dengan data jumlah kasus HBV yang jauh lebih tinggi dibanding HIV baik di Indonesia maupun di dunia (Kementerian Kesehatan, 2017; WHO, 2017).

Namun, hasil penelitian yang didapat cukup berbeda dengan data yang dikeluarkan oleh Dinas Kesehatan Kota Cimahi, dimana tidak ditemukannya kasus infeksi HBV di kota tersebut (Dinas Kesehatan Kota Cimahi, 2017). Salah satu faktor yang menjadi penyebab perbedaan tersebut adalah cara Dinas Kesehatan mendapatkan data. Umumnya Dinas Kesehatan mendapatkan data dari rumah sakit dan kegiatan surveilance yang dilakukan dengan metode wawancara kepada masyakarat. Data yang didapatkan melalui wawancara tersebut tidak terlalu akurat karena beberapa hal, antara lain ketidakpahaman responden terhadap pertanyaan yang diajukan, sikap acuh responden terhadap kondisi kesehatannya, dan sifat responden yang cenderung berbohong ketika diajukan pertanyaan terkait hal-hal yang dianggap tabu atau memalukan.

Jika dilihat dari data yang didapatkan, infeksi HIV dan HBV pada kalangan remaja di Kecamatan Cimahi Selatan dipengaruhi oleh karakteristik sosio demografi (Tabel 3). Usia termasuk faktor yang berpengaruh secara signifikan terhadap prevalensi HIV dan HBV dengan nilai $p<0,05$. Kasus infeksi HIV dan HBV hanya terjadi pada remaja usia 18-19 tahun. Hasil ini sejalan dengan penelitian Kapata et al. (2016). Dalam penelitiannya, tercatat dari 44 orang remaja (15-19 tahun) yang positif HIV, mayoritas berusia 18 tahun. Hal tersebut dapat terjadi karena usia 18 tahun merupakan masa transisi dari remaja menuju dewasa. Pada masa transisi biasanya seorang anak melakukan pencarian jati diri dan sering kali orang tua tidak banyak terlibat atau mengawasi proses tersebut. Kondisi ini menyebabkan anak dapat melakukan hal-hal yang membahayakan kesehatan dan masa depannya.

Selain usia, ternyata pendidikan pun berpengaruh secara signifikan $(p<0,05)$ terhadap infeksi HIV dan HBV. Semua responden yang terinfeksi virus tersebut memiliki pendidikan yang rendah. Hasil serupa dilaporkan oleh Eke et al. (2015) dan Kapata et al. (2016). Dalam penelitian mereka, terlihat bahwa mayoritas responden yang terinfeksi HIV dan HBV adalah remaja dengan pendidikan dan status sosial yang rendah serta tidak memiliki pekerjaan. Beberapa 
penelitian lain juga membuktikan bahwa orang yang kurang pengetahuannya beresiko lebih tinggi tertular suatu penyakit dibandingkan dengan orang yang berpengetahuan cukup (Syarif dan Tafa, 2008; Maryati, 2009).

Menurut Media (2016), pengetahuan seseorang terhadap suatu penyakit dapat berpengaruh terhadap pencegahan penyakit tersebut. Selain itu, menurut Sudikno et al. (2011), pengawasan dan pengarahan dari orang tua juga dibutuhkan untuk mencegah infeksi HIV dan HBV di kalangan remaja. Hal tersebut terbukti melalui penelitian ini. Semua remaja yang terinfeksi HIV dan HBV bekerja sebagai pengamen. Anak jalanan atau pengamen tidak mendapatkan pengawasan orang tua terkait kesehatan dan gaya hidupnya. Anak-anak tersebut hidup berkeliaran di jalanan tanpa arahan dari orang dewasa untuk menjalani hidup yang lebih berkualitas.

Selain karakteristik sosio demografi, ternyata ada beberapa karakteristik gaya hidup yang mempengaruhi tingkat prevalensi HIV dan HBV pada remaja di Cimahi Selatan (Tabel 4). Hubungan seksual merupakan salah satu faktor yang berpengaruh pada infeksi HIV dan HBV. Satu orang yang positif terinfeksi HIV dan dua orang yang terinfeksi HBV mengaku pernah melakukan hubungan seksual, sering bergantiganti pasangan, dan tidak menggunakan kondom. Mengingat jalur transmisi kedua virus tersebut adalah melalui hubungan seksual, maka data yang didapatkan ini sesuai.

Hasil tersebut ternyata sejalan pula dengan penelitian yang dilakukan Viegas et al., (2015). Tercatat sebanyak $78,9 \%$ remaja yang melakukan hubungan seksual pada usia kurang dari 18 tahun terinfeksi HIV. Jumlah kasus HIV dan HBV lebih banyak terjadi pada remaja yang sering berganti-ganti pasangan $(88,7 \%)$. Selain itu, $63,4 \%$ orang yang terinfeksi HIV tidak pernah atau jarang menggunakan kondom. Kambu (2012) juga menyebutkan bahwa infeksi HIV lebih banyak terjadi pada kelompok usia 1235 tahun karena banyak melakukan aktivitas seksual yang tidak aman, seperti sering berganti pasangan dan tidak menggunakan kondom.

Berganti-ganti pasangan seksual sudah pasti menjadi penyebab tingginya prevalensi HIV dan HBV. Orang yang berganti-ganti pasangan seksual pasti tidak mengetahui semua status kesehatan pasangannya. Ketika seseorang melakukan hubungan seksual dengan orang yang terinfeksi HIV atau HBV maka orang tersebut akan tertular dan berpotensi menularkan virus tersebut pada pasangan selanjutnya. Oleh sebab itu, penggunaan kondom sangat disarankan.
Menurut Ortiz et al. (2011) dan Brook (2006), penggunaan kondom pria secara benar dan konsisten merupakan cara yang efisien dan tidak mahal untuk mereduksi resiko Infeksi Menular Seksual (IMS) seperti HIV dan HBV. Kondom dapat mencegah terjadinya kontak langsung antara organ reproduksi laki-laki dengan perempuan sehingga mereduksi penularan virus melalui cairan tubuh.

Selain kebiasaan berganti-ganti pasangan dan tidak menggunakan kondom, ternyata kebiasaan melakukan hubungan seksual secara oral pun berpengaruh pada penularan infeksi HIV, walaupun tidak signifikan. Dari 4 orang remaja yang mengaku pernah melakukan hubungan seksual dengan cara tersebut, satu orang diantaranya terinfeksi HIV. Selama ini orang beranggapan bahwa HIV hanya dapat ditularkan melalui hubungan seksual vaginal. Ternyata ada beberapa penelitian yang membuktikan bahwa hubungan seksual secara oral juga dapat menyebabkan penularan HIV, walaupun resikonya $1 / 10$ lebih rendah dibandingkan hubungan seks vaginal (Romano et al., 2002; Varghese et al., 2002).

Faktor lain yang berhubungan dengan tingkat penyebaran HIV dan HBV pada remaja adalah tato dan tindik. Bahkan, tindik terbukti berpengaruh secara signifikan $(p<0,05)$ terhadap prevalensi HBV. Sekarang ini, tato dan tindik bukan saja dimiliki oleh sekelompok penjahat atau komunitas tertentu melainkan sudah menjadi tren di kalangan anak muda (Heywood et al., 2012). Kebanyakan dari mereka membuat tato dan tindik sebagai salah satu cara untuk mengekspresikan diri (Makkai dan McAlliester, 2001). Namun, tato dan tindik dilarang keras oleh pihak sekolah atau perguruan tinggi oleh sebab itu, seorang pelajar jarang memiliki tato atau tindik. Hal tersebut terbukti melalui penelitian ini. Responden yang menggunakan tato dan tindik hanyalah anak pengamen.

Tato dan tindik sudah tidak asing lagi bagi sekumpulan anak-anak tersebut. Beberapa dari mereka mempunyai tato dengan jumlah lebih dari satu. Bagian tubuh yang ditindik pun beragam, mulai dari telinga, alis, bibir, hingga lidah. Menurut pengakuan beberapa anak pengamen, mereka saling menato dan menindik tubuh temannya dengan alat seadanya. Hal ini dikarenakan keterbatasan uang yang mereka miliki.

Penggunaan jarum yang terkontaminasi pada pembuatan tato dan tindik dapat menjadi faktor resiko penularan HIV dan HBV (Samuel et $a l .$, 2001). Beberapa penelitian lain juga berhasil membuktikan bahwa perilaku menindik tubuh 
dengan alat yang tidak steril dapat meningkatkan resiko penularan HBV (Jafari et al., 2012; Yang et al., 2015). Penelitian Naully et al. (2017) membuktikan bahwa adanya dua kasus infeksi HIV, dua kasus HBV, dan satu kasus Hepatitis C (HCV) pada kelompok orang bertato di Cimahi. Bahkan ditemukan satu kasus koinfeksi HIVHBV pada kelompok tersebut (Naully, 2018). Shahri et al. (2016) menyebutkan bahwa sekecil apapun tato yang dimiliki tetap akan meningkatkan resiko penularan HIV, HBV, dan $\mathrm{HCV}$.

Hal terakhir yang memiliki pengaruh signifikan terhadap $(p<0,05)$ penyebaran $\mathrm{HBV}$ pada kalangan remaja di Cimahi Selatan adalah vaksinasi hepatitis B. Dua orang remaja yang terinfeksi HBV mengaku belum pernah melakukan vaksinasi hepatitis B. Hal tersebut menunjukkan bahwa di dalam tubuh kedua anak tersebut belum terbentuk antibodi anti-HBs yang dapat mencegah infeksi HBV. Walaupun ada kemungkinan kedua remaja tersebut pernah mendapatkan vaksinasi hepatitis B ketika bayi, belum tentu titer antibodi anti-HBs yang terbentuk mencapai tingkat protektif. Titer antiHBs yang bersifat protektif adalah lebih dari 10 IU/ml (Hammittet al., 2007).

Menurut Batista et al. (2006), vaksinasi merupakan cara yang ampuh untuk mencegah infeksi HBV. Dalam penelitiannya, Brook (2006) juga telah membuktikan bahwa vaksinasi dapat mencegah terjadinya koinfeksi HBV pada orang yang terinfeksi HIV. Bahan utama vaksin hepatitis B adalah HBsAg yang merupakan antigen permukaan HBV (Madigan et al., 2012). Antigen tersebut dapat menginduksi tubuh membentuk antibodi anti-HBs yang berfungsi untuk mencegah penempelan HBsAg ke permukaan sel inang (Kudesia dan Wreghitt, 2009). Walaupun anti-HBs bertahan lama di dalam tubuh, titer anti-HBs akan mengalami penurunan seiring bertambahnya waktu. Umumnya titer anti-HBs akan menurun setelah 5 sampai 10 tahun paska vaksinasi (Damme, 2016). Oleh sebab itu, disarankan untuk melakukan vaksinasi ulang atau booster untuk meningkatkan titer anti-HBS (Mulyani dan Rinawati, 2013).

Hasil pemeriksaan laboratorium yang didapatkan dalam penelitian ini didukung pula dengan gejala klinis yang dialami oleh responden (Tabel 5). Seorang responden yang terinfeksi HIV mengaku pernah mengalami penurunan berat badan yang cukup signifikan yaitu sekitar $10 \%$ dari bobot tubuhnya dalam jangka waktu yang singkat, kurang dari 1 bulan. Gejala tersebut umumnya muncul pada stadium klinis tahap 2, yaitu sekitar 3 bulan sampai 5 tahun setelah terinfeksi HIV (Kudesia dan Wreghitt, 2009). Selain itu, responden tersebut mengaku pernah mengalami diare yang berkepanjangan sekitar dua bulan yang lalu. Hal ini juga termasuk gejala klinis yang biasanya timbul dari orang yang terinfeksi HIV (Madigan et al., 2012).

Satu dari dua orang yang positif $\mathrm{HBsAg}$ mengaku pernah mengalami infeksi kelamin. Kondisi ini memang bukan merupakan gejala klinis dari penyakit Hepatitis B, namun dilihat dari kebiasaan orang tersebut yang sering melakukan hubungan seksual secara tidak aman maka besar kemungkinannya dia pernah mengalami IMS seperti sifilis atau penyakit kelamin lainnya. Hal ini menunjukkan bahwa gaya hidup bebas dapat menyebabkan berbagai penyakit bagi tubuh.

Data dalam penelitian ini memiliki tingkat keakuratan yang tinggi walaupun memiliki beberapa keterbatasan. Keberadaan anti-HIV dan HBsAg di dalam darah responden ditentukan dengan imunokromatografi. Walaupun imunokromatografi yang digunakan memiliki sensitivitas dan spesifisitas yang tinggi, hasil yang didapatkan hanya bersifat kualitatif. Jika kadar anti-HIV dan HBsAg dalam darah masih sedikit atau dibawah rentang deteksi imunokromatografi yang digunakan maka akan menunjukkan hasil negatif palsu.

Hal tersebut perlu diperhatikan khususnya untuk infeksi HIV. Berbeda dengan HBsAg yang dapat terdeteksi tidak lama setelah infeksi, antibodi anti-HIV tidak akan terbentuk seketika. Dibutuhkan waktu sekitar satu sampai tiga bulan hingga anti-HIV terbentuk dalam tubuh (Kudesia dan Wreghitt, 2009). Kondisi tersebut disebut dengan window periode. Hal ini menunjukkan bahwa kasus HIV yang terjadi pada 100 orang responden dalam penelitian ini bisa saja lebih dari satu. Tidak ditutup kemungkinan ada beberapa remaja yang terinfeksi HIV namun belum memproduksi anti-HIV dengan titer diatas rentang deteksi imunokromatografi yang digunakan. Oleh karena itu, perlu dilakukan pemantauan terkait infeksi HIV dalam jangka waktu satu hingga tiga bulan kedepan untuk memastikan status infeksi HIV pada 100 orang remaja tersebut.

\section{SIMPULAN}

Kasus infeksi Human Immunodeficiency Virus (HIV) dan Hepatitis B Virus (HBV) pada kalangan remaja usia 15-19 tahun ditemukan di Kecamatan Cimahi Selatan dengan prevalensi 1\% untuk HIV dan 2\% untuk HBV. Tingkat 
penyebaran infeksi HIV dan HBV tersebut dipengaruhi oleh karakteristik sosio demografi dan gaya hidup remaja.

\section{SARAN}

Tindakan preventif dan penanggulangan kasus infeksi HIV dan HBV pada kalangan remaja usia 15-19 tahun perlu segera dilakukan baik oleh pemerintah melalui Dinas Kesehatan Kota Cimahi maupun oleh masyarakat secara luas.

Hepatitis B: a systematic review and metaanalysis. Canadian Journal of Public Health, 103(3), 207-212.

Kambu, Y. 2012. Analisis faktor-faktor yang mempengaruhi tindakan pencegahan penularan HIV oleh ODHA di Sorong. [Tesis]. Jakarta: Universitas Indonesia.

Kapata, P.C., Klinkenberg, E., Maddox, N., Ngosa, W., \& Kapata, N. 2016. The prevalence and socio-economic determinants of HIV among teenagers aged 15-18 years who were participating in a mobile testing population based survey in 2013-2014 in Zambia. BMC public Health, 16, 1-7.

Kementerian Kesehatan RI. 2014. Situasi dan Analisis Hepatitis. Jakarta: Kementerian Kesehatan RI.

Kementerian Kesehatan RI. 2015. Situasi Kesehatan Reproduksi Remaja. Jakarta: Kementerian Kesehatan RI.

Kementerian Kesehatan RI. 2017. Laporan situasi perkembangan HIV-AIDS \& PIMS di Indonesia. Jakarta: Kementerian Kesehatan RI.

Kudesia, G. \& Wreghitt. 2009. Clinical and Diagnostic Virology. Cambridge: Cambridge University Press.

Madigan, M., Martinko, J.M., Stahl, D.A., \&Clark, D.P. 2012. Biology of Microorganisms. 13th Ed. San Fransisco: Pearcon Education, Inc.

Makkai, T. \& McAllister, I. 2001. Prevalence of tattooing and body piercing in the Australian community. Commun Dis Intell, 25(2), 67-72.

Kementerian Kesehatan. 2015. Peraturan Menteri Kesehatan Republik Indonesia Nomor 15 Tahun 2015 tentang Pelayanan Laboratorium Pemeriksa HIV dan Infeksi Oportunistik. Jakarta.

Maryati. 2009. Pengaruh pendidikan kesehatan tentang penyakit hepatitis terhadap peningkatan pengetahuan dan perubahan sikap keluarga penderita hepatitis di RSUD 
Pandan Arang Boyolali. [Skripsi]. Surakarta: Universitas Muhammadyah Surakarta.

Media, Y. 2016. Pengembangan strategi dalam upaya penanggulangan HIV/AIDS melalui pendekatan sosial budaya di Kota Bukittinggi, Sumatera Barat. Jurnal Ekologi Kesehatan, 5(1),1-14.

Mohammadi, M., Talei, G., Sheikhian, A., Ebrahimzade, F., Pournia, Y., Ghasemi, E., \& Boroun, H. 2009. Survey of both Hepatitis B Virus (HBsAg) and Hepatitis C Virus (HCV-Ab) coinfection among HIV positive patients. Virol J., 6, 202.

Mulyani, N.S. \& Rinawati, M. 2013. Imunisasi Untuk Anak. Nuha Medika.

Murphy, K. 2012. Immunobiology. 8th Ed. New York: Garland Science, Taylor \& Francis Group.

Naully, P.G., Hilmi, D., Homis, M.M., Permata, O.I., Soviyani, R.N. 2017. An Overview of HIV, HBV, and HCV Infections among Tattooed People in Cimahi. International Seminar on Global Health.

Naully, P.G. 2018. Koinfeksi Human Immunodeficiency Virus dan Hepatitis B Virus pada orang bertato di Cimahi. Jurnal Nusantara Medika, 2(2), 1-9.

Ortiz, A.B., Carcamo, C.P., Scott, J.D., Hughes, J.P., Garcia, P.J., \& Holmes, K.K. 2011. HBV infection in relation to consistent condom use: a population-based study in Peru. PLos ONE, 6(9), 1-6.

Pratiwi, N.L. \& Basuki, H. 2011. Hubungan karakteristik remaja terkait risiko penularan HIV-AIDS dan perilaku seks tidak aman di Indonesia. Buletin Penelitian Sistem Kesehatan, 14(4), 346-357.

Purwaningsih, S.S \& Widayatun. 2008. Perkembangan HIV dan AIDS di Indonesia: tinjauan sosio demografis. Jurnal Kependudukan Indonesia, 3(2), 7595.

Romano, J. D., Marincovich, B., Castilla, J., Garcia, S., Campo, J., Hernando, V., \& Rodriguez, C. 2002. Evaluating the risk of HIV transmission through unprotected orogenital sex. AIDS, 16, 1296-1297.
Samuel, M.C., Doherty, P.M., Bulterys, M., \& Jenison, S.A. 2001. Association betweenheroin use, needle sharing and tattoos received in prison with Hepatitis B and $\mathrm{C}$ positivity among street-recruited injecting drug users in New Mexico, USA. Epidemiol. Infect, 127, 475-484.

Shahri, S.M.H., Mood, B.S., Metanat, M., Salehi, M., \& Sharifi, R. 2016. Blood-borne infections intattooed people. International Journal Infections, 3(2), 944-948.

Sudikno., Simanungkalit, B., \& Siswanto. 2011. Pengetahuan HIV dan AIDS pada remaja di Indonesia (Analisis Data Riskesdas 2010). Jurnal Kesehatan Reproduksi, 1(3), 145-154.

Syarif, F. \& Tafal, Z. 2008. Karakteristik remaja pengguna narkoba suntik dan perilaku berisiko HIV/AIDS di Kecamatan Ciledug Kota Tangerang. Jurnal Kesehatan Masyarakat Nasional, 3(2), 70-75.

Varghese, B., Maher, J.E., Peterman, T.A., Branson, B.M, \& Steketee, R.W. 2002. Reducing the risk of sexual HIV transmission: quantifying the per-act risk for HIV on the basis of choice of partner, sex act, and condom use. Sex Transm Dis, 29, 38-43.

Viegas, E.O., Tembe, N., Macovela, E., Goncalves, E., Augusto, O., Ismael, N., Sitoe, N., Schacht, C.D., Bhatt, N., Meggi, B., Araujo, C., Sandstrom, E., Biberfeld, G., Nilsson, C., Andersson, S., Jani, I., \& Osman, N. 2015. Incidence of HIV and the prevalence of HIV, hepatitis B and syphilis among youths in Maputo, Mozambique: a cohort study. PLoS ONE, 10(3), 1-15.

WHO. 2017. Global Hepatitis Report 2017. Genewa:World Health Organization.

Yang, S., Wang, D., Zhang, Y., Yu, C., Ren, J., Xu, K., Deng, M., Tian, G., Ding, C., Cao, Q., Li, Y., Chen, P., Xie, T., Wang, C., Wang, B., Yao, J., Threapleton, D., Mao, C., Ruan, B., \& Li, L. 2015. Transmission of Hepatitis B and C Virus infection through body piercing: a systematic review and meta-analysis. Medicine, 94(47), 1-14. 